\title{
Quantum-chemical modeling of hydrogen bonds in a-glycine
}

\author{
(C) Alyona A. Lysenok, ${ }^{+}$Pavel A. Kalmykov, Nina I. Giricheva, ${ }^{*}$ \\ Tatiana G. Volkova, and Elena G. Belkina \\ Department of Organic and Physical Chemistry. Ivanovo State University. \\ Ermak St., 39. Ivanovo, 153025. Russia. Phone: + 7 (84932) 37-37-03. \\ E-mail: lisenokalena1996@gmail.com
}

\begin{abstract}
*Supervising author; ${ }^{+}$Corresponding author Keywords: glycine, hydrogen bond, IR spectrum, quantum-chemical calculations, density functional theory (DFT).
\end{abstract}

\begin{abstract}
Quantum chemistry was used to simulate a fragment of $\alpha$-glycine crystal consisting of 5 and 6 glycine molecules. The $\alpha$-glycine crystal fragment model was constructed using X-ray diffraction data contained in the Cambridge Crystallographic Database (CCDC). Theoretical IR spectra were obtained. It was shown that in a fragment of a crystal, glycine molecules in zwitterionic form form N-H...O hydrogen bonds of different strength, which correspond to different frequencies of stretching vibrations $\mathrm{v}_{\mathrm{st}}(\mathrm{N}-\mathrm{H})$ of the $\mathrm{NH}_{3}{ }^{+}$group. Full optimization of glycine crystal fragments consisting of a small number of molecules, regardless of the method of calculation, leads to the agglomeration of the structure. The system forms the maximum possible number of the most durable hydrogen bonds, thereby lowering the overall energy of the system, which leads to disruption of the crystal structure of the fragment, distortion of the parameters of hydrogen bonds in the crystal, and, consequently, to an unsystematic shift in the frequencies of $\mathrm{N}-\mathrm{H}$ vibrations. To avoid this process, further modeling was performed by partially optimizing the geometry of the crystal fragment, with the positions of heavy nitrogen atoms, carbon and oxygen atoms being fixed, and only the positions of hydrogen atoms involved in the formation of hydrogen bonds were varied. Using the DFT/B3LYP/6-311G** method, the energies of donor-acceptor interaction in a fragment of a crystal, as well as its oscillation frequencies, are calculated. The calculated frequencies are consistent with the three experimental frequencies in the indicated $\mathrm{X}$-ray region. A comparison was made between the calculated and experimental frequencies of the stretching vibrations of the $\mathrm{N}-\mathrm{H}$ group of the $\mathrm{NH}_{3}{ }^{+}$group. According to the geometric characteristics of the $\mathrm{HB}$ and the energy of donor-acceptor interaction between the lone electron pairs of oxygen atoms and the $\sigma^{*}(\mathrm{~N}-\mathrm{H})$ loosening orbitals, it was found that the hydrogen bonds of $\mathrm{N}-\mathrm{H} . . . \mathrm{O}$ between molecules in one layer are stronger than between molecules in different layers of a crystal.
\end{abstract}

\section{References}

[1] E. Arunan, G.R. Desiraju, R.A. Klein, J. Sadlej, S. Scheiner, I. Alkorta, D.C. Clary, R.H. Crabtree, J.J. Dannenberg, P. Hobza, H.G. Kjaergaard, A.C. Legon, B. Mennucci, D.J. Nesbitt. Defining the hydrogen bond: An account (IUPAC Technical Report). Pure Appl. Chem. 2011. Vol.83. No.8. P.1619-1636.

[2] B.A. Kolesov. Unusual behavior of benzoic acid at low temperature: Raman spectroscopic study. Spectrochimica Acta Part A: Molecular and Biomolecular Spectroscopy. 2015. Vol.142. P.320-323.

[3] B.A. Kolesov. Experimental determination of vibrational anharmonic contributions. Raman Spectroscopy. 2013. Vol.44. P.1786-1788.

[4] A. Novak. Hydrogen bonding in solids. Correlation of spectroscopic and crystallographic data. Structure and Bonding. 1974. Vol.18. P.177-216.

[5] A.V. Vvedensky, T.V. Kartashova, and E.V. Bobrinskaya. Electrooxidation of glycine and $\alpha$-alanine on platinum. Butlerov Communications. 2009. Vol.15. No.1. P.56-64. ROI: jbc-02/09-15-1-56

[6] A.A. Lysenok, and T.G. Volkova. The quantum-chemical modeling of peptide hydrogen bonds in dimer of glycin. Butlerov Communications. 2018. Vol.53. No.1. P.91-94. DOI: 10.37952/ROI-jbc-01/18-53-1-91

[7] I.B. Dmitriyeva, A.S. Chukhno, and R.V. Novichkov. Interaction of glycine with cations of Fe(III) and $\mathrm{Ni}(\mathrm{II})$ in water solutions and on surfaces of their oxides. Butlerov Communications. 2013. Vol.35. No.8. P.133-137. ROI: jbc-02/13-35-8-133

[8] G.R. Desiraju, T. Steiner. Weak hydrogen bond in structural chemistry and biology. Oxford: Oxford University Press. 1999. P.507. 
[9] J. Bernstein. Polymorphism in Molecular Crystals. Oxford: Oxford University Press. 2008. P.424.

[10] B.A. Kolesov. Raman spectroscopy of molecular crystals: methodological features, possibilities and some results. Abstracts of the reports of the Fifth Siberian Seminar on Raman Spectroscopy.

Novosibirsk. September 28-30, 2015. P.3. (russian)

[11] M.J. Frisch, G.W. Trucks, H.B. Schlegel, G.E. Scuseria, M.A. Robb, J.R. Cheeseman, Jr.J.A. Montgomery, T. Vreven, K.N. Kudin, J.C. Burant, J.M. Millam, S.S. Iyengar, J. Tomasi, V. Barone, B. Mennucci, M. Cossi, G. Scalmani, N. Rega, G.A. Petersson, H. Nakatsuji, M. Hada, M. Ehara, K. Toyota, R. Fukuda, J. Hasegawa, M. Ishida, T. Nakajima, Y. Honda, O. Kitao, H. Nakai, M. Klene, X. Li, J.E. Knox, H.P. Hratchian, J.B. Cross, C. Adamo, J. Jaramillo, R. Gomperts, R.E. Stratmann, O. Yazyev, A.J. Austin, R. Cammi, C. Pomelli, J.W. Ochterski, P.Y. Ayala, K. Morokuma, G.A. Voth, P. Salvador, J.J. Dannenberg, V.G. Zakrzewski, S. Dapprich, A.D. Daniels, M.C. Strain, O. Farkas, D.K. Malick, A.D. Rabuck, K. Raghavachari, J.B. Foresman, J.V. Ortiz, Q. Cui, A.G. Baboul, S. Clifford, J. Cioslowski, B.B. Stefanov, G. Liu, A. Liashenko, P. Piskorz, I. Komaromi, R.L. Martin, D.J. Fox, T. Keith, M.A. Al-Laham, C.Y. Peng, A. Nanayakkara, M. Challacombe, P.M.W. Gill, B. Johnson, W. Chen, M.W. Wong, C. Gonzalez, J.A. Pople. Program package Gaussian 03, Revision B.04. Gaussian Inc.: Pittsburgh, PA. 2003.

[12] G.A. Zhurko, D.A. Zhurko. Chemcraft v. 1.4 beta. Available at: http://www.chemcraftprog.com.

[13] L.F. Power, K.E. Turner, F.H. Moore. The Crystal and Molecular Structure of a-Glycine by Neutron Diffraction - a Comparison. Acta Cryst. 1976. B32. P.11.

[14] Cambridge Crystallographic Date Centre (CCDC): http://www.ccdc.com.ac.uk.

[15] Molecular structures: Precision research methods; Translation from English Ed. Domenicano, I. Hargittai. Moscow: Mir. 1999. P.671. (russian) 